\title{
Evaluation on different fungicides against Alternaria blight of cabbage caused by Alternaria brassicae
}

\author{
M.R. DABBAS* AND SHRAWAN KUMAR
}

Vegetable Section, C.S. Azad University of Agriculture and Technology, KANPUR, U.P. (INDIA)

\section{ARITCLE INFO}

Received : 25.06 .2015

Revised : 14.08 .2015

Accepted : 29.08.2015

\section{KEY WORDS :}

Alternaria brassicae, Vegetable crop, Cabbage leag

*Corresponding author:

Email: drmrdabbas@gmail.com

\begin{abstract}
Cabbage (Brassica oleracea L. var. capitata) is second important vegetable crop of Cole group. A rich source of vitamin A, B and C it also contains minerals. The cabbage cultivars are under a great threat for profitable cultivation due to the attack of several abiotic and biotic factors viz., Fungi, Bacteria, Virus, Nematode etc. The experiment on integrated disease management of Cabbage leaf blight disease under field conditions revealed that out of 12 treatments using fungicides and bio-agent formulations was conducted during 2012-13 and 2013-14. The mean of analysis of two years data indicate that the minimum disease intensity 4.56 per cent was recorded in three foliar sprays of Acrobat @ (0.1\%)+Mancozeb@ (0.2\%) which also gave maximum yield 408.02 q/ha. Second best treatment was three foliar sprays of Ridomil MZ-72@ (0.2\%) which gave 4.60 per cent disease intensity and $373.65 \mathrm{q} /$ ha heads yield.
\end{abstract}

How to view point the article : Dabbas, M.R. and Kumar, Shrawan (2015). Evaluation on different fungicides against Alternaria blight of cabbage caused by Alternaria brassicae. Internat. J. Plant Protec., 8(2) : 299-302. 